\title{
Szempontok és módszerek a személynév és etnikum összefüggésének vizsgálatához*
}

1. A tulajdonnevek történettudományi forrásértékéről. A tulajdonnevek kiemelt történettudományi forrásértékét (főként a magyar írásbeliség korai időszakát illetően) tudománytörténeti jelentőségű munkák sora igazolja (MELICH 1925-1929, KNIEZSA 1938; az utóbbi évtizedekből pl. KRISTÓ 2000, BENKŐ 2002). A vizsgálatok között - érthető módon - kiemelt figyelmet kapott a Kárpát-medence korai ómagyar kori etnikai összetételének meghatározása. Az etnikai rekonstrukcióhoz felhasznált tulajdonnévfajták közül a korai időszakra vonatkozólag a helynevek élveztek elsőbbséget a személynevekkel szemben (az előbbiek kutatástörténeti áttekintésére 1. pl. PóczOS 2010: 11-34). A helynévrekonstrukció eredményeire épülő népiségtörténeti következtetések azonban HoFFMANN ISTVÁN, illetve munkatársai szerint módszertani szempontból alapvető pontokon szorulnak felülvizsgálatra, így ezeket jelenleg erös kritikával kell kezelnünk (HOFFMANN 2007, 1. még HOFFMANN-TÓTH 2016, HOFFMANN-RÁCZ-TÓTH 2018: 459-470).

A személynevek háttérbe szorulásának okaként KRISTÓ GYULA a kora Árpád-korra nézve az adatok gyér volta mellett a névdivat hatását jelöli meg, amelyek nagymértékben korlátozzák és bizonytalanná teszik az etnikai háttér feltárását (KRISTÓ 2000: 30), ugyanakkor elfogadhatónak tartja FEHÉRTÓI KATALIN 12-13. századi adatokra épülő rekonstrukciós eljárását (FEHÉRTÓI 1997), melynek révén az alsóbb társadalmi rétegek személyneveinek eredete alapján következtet a korabeli etnikai arányokra. TÓTH VALÉRIA és HOFFMANN ISTVÁN szerint azonban ,a személynevek nyelvi eredete, etimológiai származása nem kapcsolható közvetlenül, mechanikusan össze a kérdéses nevet viselő személy nyelvi-etnikai hovatartozásával. A személynévkincsnek közvetlen nyelvi-etnikai forrásértéke aligha lehet" (HOFFMANN-TÓTH 2015: 15; kiemelés tőlem; 1. még HOFFMANN 2010: 55-56, TÓTH 2013: 247). Ez a megállapítás nem sok reményt ígér a személynévi alapú etnikai rekonstrukció eredményességére nézve. Véleményem szerint azonban a kijelentés - azon túl, hogy fokozott óvatosságra inti a kutatót - általános érvénnyel nem vonatkoztatható a személynévtörténet teljes szakaszára. Más módszertani követelményeket kell ugyanis szem előtt tartani az egytagú (egyelemü, egybázisú, egyrészes) névrendszer korai adatai, illetve a családnevek 14-15. századi kialakulásával kezdődő időszak forrásainak elemzése során.

Tanulmányomban a családnevek hivatalossá válását megelőző időszak forrásanyagának nyelvi-etnikai célú felhasználásához kívánok elemzési szempontokat adni. A felső időhatár megvonását az indokolja, hogy a családnevek etnikumjelző funkciójára a családnévváltoztatások alapvető hatást gyakoroltak: a közösségi alapú spontán névváltozások helyébe

\footnotetext{
* A tanulmány a Magyar Tudományos Akadémia Bolyai János Kutatási Ösztöndíja és a Nemzeti Kutatási, Fejlesztési és Innovációs Hivatal (NKFIH) 116414. nyilvántartási számú szerződése támogatásával készült.
} 
ugyanis az egyéntől származtatható, tudatos névváltoztatások léptek. A névváltoztatók pedig sok esetben a modern nemzetfogalom szerinti identitásvállalás kifejező jegyeként tekintettek a családnévre (erre 1. bővebben pl. FARKAS 2009a, 2009b).

2. Személynév, nyelv és etnikum összefüggése. Annak megválaszolása érdekében, hogy milyen szerepet játszanak a vizsgált időszak történeti személynevei az etnikai rekonstrukcióban, egyrészt magát az etnikum (ethnosz) fogalmát szükséges definiálnunk, megkeresve a nyelv helyét a meghatározásában. Másrészt arra a kérdésre kell válaszolnunk, hogy milyen következtetéseket vonhatunk le a személynév alapján a nyelvre vonatkozóan, azaz milyen forrásértékük lehet az egyes személynévfajtáknak a nyelvi rekonstrukcióban, illetőleg a „beazonosított” nyelv hogyan kapcsolódik a névadói-névhasználói közeghez.

2.1. Az etnikum fogalma. Elsőként tehát arra a kérdésre keressük a választ, hogy miként határozható meg az etnikum fogalma, illetve hogy a nyelv milyen módon kapcsolódik az etnikumhoz.

RÓNA-TAS ANDRÁS szerint „népnek (vagy idegen szóval ethnosznak) azt a történetileg kialakult embercsoportot nevezzük, amelynek közös a kulturális jelrendszere, amely tudatosan megkülönbözteti magát más népektől, s amelynek saját, tartós önelnevezése van" (RÓNA-TAS 1996: 24; kiemelés tőlem). Azt, hogy mi tartozhat a kulturális jelrendszerbe, egy 6. századi bizánci forrásból is tudjuk: e szerint egy sztyeppei türk nép (utrigur) azért nem támadott meg egy másik türk népet (a kutrigurokat), mert ,azok velük azonos néphez tartoznak, velük közös nyelvet beszélnek, lakásaik, ruházatuk és életmódjuk hasonló az övékhez és azonos a leszármazásuk is, noha más fejedelmeknek engedelmeskednek" (RÓNA-TAS 1996: 23). RÁCZ ANITA a fogalom magyarázatainak tudománytörténeti áttekintésében az etnikumjelölő kritériumok között a közös szemiotikai rendszert (pl. nyelv, tárgyi kultúra, viselet), a közös származástudatot, a közös földrajzi és politikai keretet, a csoport antropológiai sajátosságait, a „mi-tudatot” és a népnevet (önelnevezést) sorolja fel (RÁCZ 2016: 15-24). (A fogalom bővebb magyarázatára 1. még RÓNA-TAS 1997, BÁLINT 2006, RÁCZ 2013.) Ebben a meghatározásban a közös kulturális jelrendszer összetett fogalomként értelmezendö, amelynek a közös nyelv csak az egyik alkotóeleme.

Az etnicitás többdimenziós fogalomként, hasonló összetevőkkel jelenik meg a személynevek és az etnikum összefüggésével foglalkozó külföldi szakmunkákban is (vö. pl. BHOPAL 2004: 442, MATEOS 2014: 103). MARTIN BULMER (1996) szerint az etnikai csoporthoz tartozóknak valódi vagy feltételezett közös ősei vannak, a közös múlt emlékeit hordozzák, és egy vagy több szimbolikus elem határozza meg a csoportot. Az utóbbiak közé a vallást, a nyelvet, a közös területet és a fizikai megjelenést sorolja (BULMER 1996: 35). RAJ BHOPAL (2004) szerint az etnicitás kritériumai közé bizonyos közös jellemzők, például a földrajzi eredet, a származás, a kulturális hagyományok és a nyelv tartoznak. Kiemeli, hogy ezek a jellemzők nem állandóak (képlékenyek), ezért nehezen mérhetők (BHOPAL 2004: 441-442). A csoportidentitást általában a kulturális szempontból eltérőnek tartott csoporttal szembeni önmeghatározás hozza létre, ehhez pedig rendszeres kapcsolatra van szükség az érintett csoportok között: ennek révén válhat világossá 
a kulturális különbözőség (ERIKSEN 2002: 12). Az etnikai csoport létrejöttét pedig legegyértelmübben az önelnevezés (népnév, etnonima) szimbolizálja. ${ }^{1}$

Az etnicitással kapcsolatos problematika összetettségét és bizonytalanságát tovább fokozza az egyéni identitások szempontjainak figyelembevétele. Az egyéni azonosságtudat ugyanis nem feltétlenül egyezik meg a csoportidentitás felsorolt jellemző kritériumaival: lehet például a jellemző jegyek valamelyikét (vagy szélsőséges esetben: mindegyikét) nélkülöző egyéni vállalás és meggyőződés eredménye is. Nem feltétlenül szükséges például az etnikummal való azonosuláshoz a genetikai kapcsolat vagy a fizikai hasonlóság megléte (MATEOS 2014: 14). Végső soron tehát az etnikum fogalmának középpontjában az egyén identitásának kérdése áll, amelyet azok az etnikai csoporthoz kapcsolódó sajátosságok határoznak meg, melyeket az egyén magára vonatkozónak tekint (erre 1. pl. PEACH ed. 1996). Ez a meghatározás különbséget tesz a csoportazonosság jegyeinek kollektív meghatározása és az egyén identitásvállalása között. Az utóbbit az egyéni szubjektum olyan mértékben befolyásolja, hogy feltárása csak az egyén közremüködésével (saját nyilatkozata révén) lehetséges; ${ }^{2}$ erre azonban a történetiségben már nincs lehetöség, napjainkban is csak korlátozottan.

A fent elmondottak szerint a népi önazonosság-tudatot összetett viszonyrendszer határozza meg, amely a közös nyelvet ugyan jellemzőnek, de nem kizárólagosnak tartja az etnicitás fogalmának meghatározásakor. „Ha ebből a bonyolult viszonyrendszerből egyegy összetevőt kiemelünk és megvizsgálunk, azt annak tudatában tehetjük csak, hogy általa nem a maga komplexitásában adunk képet az etnikumról, hanem csupán az egyik jellemzőnek tekintett jegyét ismerhetjük meg ezzel a módszerrel" (HOFFMANN-RÁCZTÓTH 2018: 459). Ismerünk olyan jelenkori és történeti példákat, amelyekben azonos nyelvet beszélö, különböző népeket tudunk elkülöníteni, ugyanakkor vannak magukat azonos etnikumhoz tartozónak valló, de különböző nyelveket használó csoportok.

Nem vitatva ugyan, hogy nyelv és etnikum közé egyenlőségjelet tenni a fentiek miatt nem lehet, a túlzott óvatosság követése két okból sem tünik célszerünek. Egyrészt ha az

\footnotetext{
${ }^{1}$ A Kárpát-medencében megtelepedő különböző etnikai csoportok korai elkülönítését és azonosítását jól jelzik a tulajdonnévi funkcióban megjelenő, etnikai csoportokra történő utalások (a helynévi példákra 1. RÁcz 2011). A korai családnévi adatok szintén egyértelműen igazolják, hogy a leíró személynévadás egyik gyakori módja volt az etnikumra (népnévvel) történő utalás már e személynévfajta kialakulásától kezdődően. (Megjegyzem, hogy ez akkor is igaz, ha bizonyos esetekben a népnév más sajátosságjegyeket, például tulajdonságot, eseményt is kifejezhetett.) A FelsőTisza-vidék 15. századi magyar családnévanyagának gyakorisági listájában például két etnonima is előkelő helyen szerepel: a Tót az első helyen (3,38\%-os, nagyon magas aránnyal), a nyolcadikon pedig az Oláh (N. FODOR 2010: 97). Arra, hogy a népnévi személynévadás általánosan elterjedt volt az egész Kárpát-medencében, a mai névgyakoriság is egyértelmüen utal. 2007-ben Magyarországon a harmadik leggyakoribb családnév a Tót $(2,17 \%)$, az ötödik a Horvát $(1,99 \%)$, a kilencedik a Német $(0,95 \%)$, a tizennyolcadik az Oláh $(0,38 \%)$ volt (N. FodOR 2010: 102, 1. még FARKAs 2013: 505-506). Az is tény, hogy Európa más részein a népnévi eredetű családnév jóval ritkább (pl. Olaszországban az első 50 családnévben nincs etnonima), aminek történelmi és kulturális okai egyaránt lehetnek (FARKAS 2013: 507).

${ }^{2}$ A kérdést tovább bonyolítja az, hogy az egyéni kettős vagy többes identitás sem példa nélküli.
} 
egyes, általunk vizsgált (Kárpát-medencei) népeket nézzük, akkor talán a szláv nyelvű csoportok elkülöníthetőségének nehézségeit, illetőleg a magyarságba olvadt, nyelvcserén átesett népeket leszámítva egyéb (a 18. század elején releváns) esetekben egyértelmünek tünik a nyelv és az etnikum összefüggése. Másrészt a tudományos kutatás lehetőségeit számba véve - KRISTÓhoz hasonlóan - arra a következtetésre juthatnunk, hogy az „etnikumokat elválasztó ismérvek közül a legtöbbnek nincs forrásos bázisa, ennélfogva kívül esnek a tudományos vizsgálódás határain" (KRISTÓ 2000: 11, 1. még HOFFMANN-RÁCZTóTH 2018: 460). Azaz ha a korábbi századok etnikai viszonyait kívánjuk feltárni minél nagyobb területre vonatkozóan, kénytelenek vagyunk ezt elsődlegesen a tulajdonnevek, a későbbi századokra nézve pedig egyre hangsúlyosabban a személynevek felhasználásával megtenni. További megoldásként csupán a szórványos történeti adatok figyelembevétele kínálkozik, vagy pedig teljesen le kell mondanunk az etnikai alapú vizsgálati lehetőségről.

Továbbra is kérdés marad ugyanakkor, hogy hogyan viszonyuljunk az egyéni nyelvhasználatnak (bizonyos esetekben) a kollektív kritériumoktól eltérő sajátosságaihoz. Az ellentmondás abban áll, hogy noha az etnikumtörténeti vizsgálatok is a közös nyelv tanulságaira építenek, az utóbbi meghatározása az egyénhez kapcsolható információk (pl. a személy elnevezése) alapján történik. (A 4. pontban majd ennek az ellentmondásnak a feloldására teszek javaslatot.)

2.2. Személynéveredet és etnikai rekonstrukció. A továbbiakban röviden szükséges kitérnünk a személynév etnikai rekonstrukciós forrásértékére, és arra, hogy mit tükröz valójában a név nyelvi eredete: a névviselö vagy a névadó környezet nyelvi-népi hovatartozását.

A személynév bizonyos típusainak (elsődlegesen a természetes módon keletkező leíró neveknek, például a mindenkori ragadványneveknek) van a legszorosabb kapcsolatuk a nyelvi rendszerrel, annak szókészletéből, saját szabályai szerint (névalkotással) jönnek létre és változnak. Más személynévfajták (pl. a referáló típusú egyénnevek) viszont a külső tényezők (a kultúra, divat stb.) változásának vannak jobban kitéve, ezért számos jövevényelemet tartalmaznak (az elkülönítésre 1. pl. TóTH 2016). Mint láttuk, az utóbbi csoport felhasználhatósága a fenti sajátosságjegyek miatt megkérdőjeleződött a korai időszakra vonatkozó etnikai vizsgálatokban. A későbbiekben arra is kitérek, hogy erről a forráscsoportról sem kell az etnikai célú vizsgálatoknak teljesen lemondaniuk, de ezt megelőzően szükséges a természetes módon keletkező családnév(előzmény)ek jellemző sajátosságainak az áttekintése.

A magyar személynévtörténetben a családnevek kialakulásának kezdete a 14. századra tehető. A kéttagú (kétbázisú, kételemü, kétrészes) névrendszer általánossá válásának folyamata viszonylag gyorsan, egy-másfél évszázad alatt végbement. A Felső-Tisza vidékén például az 1401-1526 közötti időszakban már a névviselök 82,2\%-ának volt valamilyen megkülönböztető másodlagos neve az egyénnevük (keresztnevük) mellett, 15,1\%-ot körülíró névszerkezettel jelöltek, és mindössze $2,7 \%$ volt az egytagú névvel feljegyzettek aránya (vö. FTSznSz. 14). Általánosan elfogadott tény, hogy a természetes névadásban ide sorolhatók az egyén sajátosságjegyeit tükröző családnévelőzmények is - az elnevező 
maga a közösség ${ }^{3}$, amely a maga anyanyelvén nevezi meg az együvé tartozókat vagy az oda újonnan érkező egyént, akkor is, ha az egy másik etnikumból származik (erre 1. a népnévi eredetű családnevek tanulságait). Ez pedig azt eredményezi, hogy a név nyelvi eredete és az elnevezett egyén etnikuma közé nem lehet egyértelműen egyenlőségjelet tenni már a névkeletkezés pillanatában sem. A későbbiek során azonban - amennyiben nem tömeges betelepedésről van szó - feltételezhető, hogy az elnevezett egyén asszimilálódik a környezetéhez.

A török hódítás századaiban a belső migráció felerősödésével kell számolnunk, amely a Kárpát-medencei névrendszerek egymásra hatásának fokozódását eredményezi. Az idegen nyelvi környezetbe kerülö, majd egy-két generáció alatt asszimilálódó család esetében a magukkal hozott családnév utóélete kétféleképpen alakulhat: egyrészt (a névviselés hivatalossá tételéig) spontán módon megváltozhat immár az új környezet nyelve szerinti névformára (névasszimiláció), ${ }^{4}$ másrészt az egyéni (családi) asszimiláció az eredeti családnév fennmaradásával történik meg. (A téma szakirodalmából 1. FARKAS 2009b, SZENTGYÖRGYI 2012, TÓTH 2016: 69-71.)

Az egyéni identitás és a nyelv problematikája mellé az identitás és név összefüggésének bizonytalanságai társulnak. Itt sem mondhatunk mást, csak hogy akkor járunk el helyesen, ha nem az egyes nevek mögötti névviselök etnikai hovatartozására, hanem a tágabb környezet (falu, járás, tájegység), illetve közösség nyelvi és erre épülö etnikai rekonstrukciójára helyezzük a hangsúlyt, azaz az adatok összességéből vonunk le általános következtetést; az egyén etnikumhoz kapcsolása ugyanis a név alapján nem mindig vezet eredményre. Az alábbiakban amellett kívánok érvelni, hogy mindezek ismeretében a személynévi adatokat (bizonyos kritériumok mentén) felhasználhatjuk az etnikai elemzésekhez.

3. A Kárpát-medencei etnikai térszerkezet kutatása a személynevek alapján. A történettudományi kutatások természetesen nemcsak a Kárpát-medence honfoglalás kori és kora Árpád-kori népi viszonyainak feltárására irányultak, hanem a későbbi évszázadok etnikai térszerkezetének változását is igyekeztek megismerni (bővebben 1. alább). Az etnikumra (vagy nemzetiségre) közvetlenül utaló népesség-összeírások azonban csak a 19. századtól kezdődően készültek, ezért a korábbi időszak vonatkozásában a beszélt nyelvet települési szinten rögzítő összeírásokat lehet csupán vallatóra fogni. A beszélt nyelvek falvankénti legkorábbi jegyzékét az 1787-ben készült Lexicon locorum tartalmazza. Az ezt megelőző korszakból nincsenek olyan, az egész Kárpát-medencére (elsődlegesen a

\footnotetext{
${ }^{3}$ A közösség meghatározása általában a lakóhely alapján történhet, de természetesen egyéb közösségek (a középkorban például a céhek, a közelmúltból a katonaság, az iskola, a munkahely stb.) természetes névadó tevékenységéről is beszélhetünk.

${ }^{4}$ Itt jegyzem meg, hogy bár az idő múlásával a családnevek kései ómagyar kori névadó közösségeitől egyre messzebb kerülünk, a spontán névváltozás továbbra is lehetővé teszi a mindenkori névhasználók nyelvi sajátosságainak érvényesülését. Emellett szól az is, hogy nagyon ritka az olyan falu, ahol a teljes közösség családnévanyagának nyelvi eredete teljesen eltér a használt nyelvtől. (A vegyes lakosságú és kétnyelvű közösségek esetei természetesen külön megítélés alá esnek.)
} 
Magyar Királyságra és Erdélyre) kiterjedő átfogó jellegű forrásaink, amelyek akár csak a nyelvhasználat segítségével közvetett módon utalnának az etnikai viszonyokra, ezért felértékelődnek azok az összeírások, amelyek a társadalom bizonyos csoportjai, főként az adózó népesség személyneveit tömegesen tartalmazzák. Abból kiindulva, hogy a családnevek utalnak a nyelvi háttérre, a nyelv alapján pedig közvetve az etnikumra, járható útnak tünt a személynevek (föként a családnevek) etnikai célú elemzése.

Az első, nagy területre kiterjedő országos összeírás Erdélyben 1713-ban, a Magyar Királyság területén pedig 1715-ben készült. Ezek és a későbbi cenzusok a vagyoni helyzetre utaló adatok mellett csupán az adófizetők nevét tartalmazzák, nemzetiségre csak a legritkább esetben utalnak, ezért esetükben leginkább a névelemzés módszerével lehetséges a csoportidentitásra való következtetés.

A személynévi alapú etnikai rekonstrukció elsősorban a történettudomány, azon belül a népiségtörténet, a történeti demográfia és a társadalomtörténet számára jelent fontos elemzési lehetőséget. A nyelvtudomány és a névtan segédtudományi szerepben szervesen és megkerülhetetlenül kapcsolódik a kérdéskörhöz. A tulajdonnév nyelvi eredetének a meghatározása nyelvtudományi (etimológiai) feladat, melynek módszertani szabályai a történettudomány számára sem hagyhatók figyelmen kívül.

3.1. Népiségtörténeti kutatási program. A személynevek felhasználása az etnikai viszonyok feltárásához a programszerüen MÁLYUSZ ELEMÉR kezdeményezésére és irányításával létrejött népiségtörténeti kutatási program keretében kezdödött el a két világháború közötti időszakban. A program az egyes közigazgatási egységek (főként az elcsatolt vármegyék) etnikai összetételének korszakokon átívelö, átfogó vizsgálatát tüzte ki célul, melyhez a nyelvtudomány módszereit és eszköztárát hívta segítségül. Az alkalmazott névelemzési eljárás kidolgozását a szlavista nyelvész, KNIEZSA ISTVÁN végezte el (1934/1965/2003). Lényegét SzABÓ ISTVÁN (1937) ekképpen foglalta össze Ugocsa megyéről írt monográfiája előszavában: „Az összegyüjtött neveket nyelvi hovatartozandóság szerint osztályoztuk. Bár a nevek nyelvenkénti minősítésével nem többet, csak a név nyelvi alakját óhajtjuk kifejezni, mivel mégis e nyelvi minősítés alapján egy-egy közösség nyelvi jellegére s ennek alapján nemzetiségére vontunk le következtetéseket, szükségesnek láttuk, hogy azokat a neveket, melyek nyelvi alakja s tartalma között a nemzetiség tekintetében ellentmondás mutatkozik vagy ellentmondás lehetősége lappang, a határozott nyelvi alak dacára is bizonytalannak tekintsük" (SZABÓ 1937: 5; kiemelés tőlem; a módszerre 1. még KNIEZSA 1941).

Nem célom a népiségtörténeti iskola tudománytörténeti értékelése (erre 1. pl. ERÖS 2013, nyelvészeti szempontból N. FODOR 2015), csupán a nyelvészeti alapú módszer egyes, figyelemre méltó elemeit emelem ki. A népiségtörténet kutatóinak óvatos eljárása szerint bizonytalan kategóriában kaptak helyet: 1. az etnonimák (Orosz, Lengyel, Muszka, Német, Török, Zsidó stb.), kivéve a nyelvileg megegyezöket (Magyar, Székely = magyar; Litva, Ruszki = szláv); 2. olyan helységnévből keletkezett családnevek, melyek nyelvi alakja nem felel meg a névadó település nemzetiségének (pl. a Bródi magyar névadással keletkezett, de Bródon ruszinok éltek); 3. a vegyes lakosságú megyék és tájegységek nevei; 4. olyan foglalkozásnevek, amelyek több nyelven is azonos vagy hasonló alakban fordulnak elő (pl. Kovács, Bodnár, Takács); 5. a közszói átvételek (1. pl. a magyar eredetü, de a ruszinban és a románban is meglévő huszár, hajdú, puskás, kocsis szavakból keletkezett neveket); 6. az olyan keresztnévi eredetü családnevek, amelyek több nyelvben is 
hasonló alakban léteznek (pl. magyar-román-szláv: Adam, Damjan, Daniel, Kozma vagy Cosma). (A módszer alkalmazására 1. pl. ICZKOVITS 1939, JAKÓ 1940, BÉLAY 1943, ILA 1944-1976.)

A népiségtörténeti kutatási módszert kétségtelen érdemei mellett (ti. kellő óvatossággal járt el a nevek minősítésekor) a szempontunkból mindenképpen kritika illetheti amiatt, hogy nem választotta szét egyértelmüen a nyelvi eredetet (,nyelvi alkatot”) és az ebből levont etnikai alapú következtetéseket. Továbbá amellett, hogy a közösség nyelviségét hangsúlyozza, mégis az egyén származását próbálja feltárni (1. pl. az etnonimák és helységnevek kapcsán alkalmazott eljárást). ${ }^{5}$

3.2. Történeti demográfiai vizsgálatok. A programszerü népiségtörténeti kutatásokat megelőzően már történetek kísérletek a személynevek etnikai rekonstrukciós célú felhasználására, a második világháborút követő hosszabb szünet után pedig néhány évtizede ismét egyre nagyobb figyelem irányul erre a témára.

3.2.1. A történeti demográfiai vizsgálatok keretén belül - tudomásom szerint ACSÁDY IGNÁC (1896) alkalmazta elsőként a névelemzés módszerét a 18. század eleji Magyarország etnikai viszonyainak a feltárásához. A név és etnikum összefüggése kapcsán ACSÁDY felteszi a kérdést, hogy „lehet-e valakinek vezetéknevéböl következtetést vonni a nemzetiségére" (ACSÁDY 1896: 46), s az igenlő választ statisztikai számításokkal adja meg. Az 1715-ös és 1720-as országos összeírásokra támaszkodva területi egységenként mutatja be a személynevek nyelvi arányait. Módszeréről az alábbi idézetek nyújtanak eligazítást. A táblázatok rovatai „nem szorosan a nemzetiségi megoszlást akarják feltüntetni, hanem csupán azt, mennyi a név szerint felsorolt lakosságból magyar, német, tót, vagy ruthén, szerb-horvát és oláh nevü. [...] A fentebbi összesítésben azonban a név már azonosítva van a nemzetiséggel, de tisztán csak a rövidség okáért, technikai szempontból” (ACSÁDY 1896: 48; kiemelés tőlem). Arról, hogy az egyes nevek nyelvekhez rendelése hogyan történt, ezt olvashatjuk: ,a nevek megállapítása az egyes községekben elöítélet és irányzatosság nélkül történt a szerint, a mint a nevek hangzanak vagy olvashatók voltak" (ACSÁDY 1896: 48). A fentiekhez hasonlóan arról sem kapunk pontos információt, hogy az eredet szerinti besorolásnál a szerző a családneveken túl figyelembe vette-e a keresztnevek tanulságait. Ugyanakkor megjegyzi, hogy bizonyos falvakat, amelyekben a lakosok magyar nevet viselnek, az összeírók ruszinként vagy románként írnak le. Ezekben az esetekben módosította az etnikai megoszlás statisztikai adatait.

\footnotetext{
${ }^{5}$ BAgdi RóBert és DeMETer GÁBor szerint „bár a »névvegyelemzésnek« a 20. században szomorú következményei voltak, a statisztikai kimutatások megjelenéséig, mint munkamódszer nem hagyható figyelmen kívül" (BAGDI-DEMETER 2004: 361). A szerzők a népiségtörténeti iskola müveit (l. fenn) adják meg a kijelentés hivatkozásaként mint a munkamódszer korai példáit. A „,szomorú következmények" kapcsán kifejtetlenül is nyilvánvalóan azokra az esetekre céloztak, amikor a nevek alapján erőszakos identitásváltásra kényszerítettek nem magyar nevü, de magyar etnikumú személyeket (1. pl. a „reszlovakizáció” eseteit), vagy a családnéveredet alapján tekintettek valakit németnek, és hurcolták el vagy telepítették ki.
} 
ACSÁDY eljárásának szakszerüségét megkérdőjelezi, hogy kivétel nélkül minden családnevet valamelyik nyelvhez hozzá tudott kapcsolni. ${ }^{6}$ Módszertanilag ugyanis nehezen elképzelhetö, hogy ne maradnának bizonytalan vagy többes besorolású nevek egy nagyobb névanyag etimológiai elemzésekor.

3.2.2. Az újabb (az 1980-as évektől kezdődő) történeti demográfiai jellegű vizsgálatok szintén nagy mértékben támaszkodnak a névelemzés módszerére a 19. századot megelőző időszak csoportidentitásainak meghatározásában. DÁVID ZOLTÁN 17. századi dézsmajegyzékek névadatai alapján vont le következtetéseket a szlovák-magyar nyelvhatár elhelyezkedésére, a későbbi összeírások felhasználásával pedig az etnikai összetétel változására nézve (DÁVID 1993, 1995). Módszere annyiban tér el a népiségtörténeti iskola eljárásától, hogy elveti a nevek egyenkénti vizsgálatát, arra hivatkozva, hogy ,,a különböző névalakok minősítése, nemzetiség szerinti szétválasztása nem mindig lehetséges" (DÁVID 1993: 11). A bizonytalan besorolású nevek között a több nyelvhez kapcsolhatókat és a népnévi eredetü neveket emeli ki. Az előbbiek kapcsán nem tartja elfogadható eljárásnak sem valamelyik nyelvhez való önkényes rendelésüket, sem pedig bizonytalan kategóriába sorolásukat. Véleménye szerint a népesség nemzetiségét a családnevek alapján nem lehet számszerüen meghatározni. ${ }^{7}$ A minősítés alapjául ezért a „helység névanyagának általános jellege" szolgál, azaz a többségi néveredet alapján tekint egy települést szlovák vagy magyar lakosságúnak. DÁVID szerint a többségtől eltérő, egy-két bizonytalan vagy más nyelvhez kapcsolható alakok a falu etnikai besorolásán nem változtatnak (DÁVID 1993: 11). Az azonban továbbra is kérdés, hogy mikortól tekinthetünk egy települést egyértelmúen egy adott nemzetiséghez tartozónak, azaz hol (mennyi kivétel esetén) kezdődik a vegyes lakosságú települések kategóriája.

3.2.3. A történeti demográfusok a személynévi alapú rekonstrukciós eljárás megbízhatóságát egy kontrollvizsgálattal igyekeztek alátámasztani. A Somogy vármegyei inszurgens lovasság (nemesi felkelők) 1744. évi összeírásában a katonák nevén kívül a születési helyük és az önbevallás alapján rögzített anyanyelvük is szerepel, ezáltal legalább a személynév és a nyelv összefüggésébe betekintést nyerhetünk (DEMETER 2009: 5-6). A két adatsor eredményeit összevetve (1. táblázat) látható, hogy az egyes nyelvek teljes anyaghoz viszonyított eltérése (hibahatára) 5\% alatt marad. A különbség a szlovák nyelv esetében a legnagyobb: kétszer annyian vallják anyanyelvüknek a szlovákot, mint

\footnotetext{
${ }^{6}$ Néhány esetben az adózó háztartások és az osztályozott családnevek száma nem fedi egymást, mert az előbbibe a név nélkül felsorolt, adózási szempontból nem egyértelmủ besorolású csoportok (pl. kereskedök, mesteremberek) is belekerültek (ACSÁDY 1896: 46).

${ }^{7}$ DÁvID az elutasítást az alábbiakkal indokolja: „Nem vagyok tehát híve az aprólékos méricskélésnek, nem kívánom egy-egy falu nemzetiségi összetételét a családnevek alapján szám szerint megállapítani - nemcsak, mert nem vagyok nyelvész, s mert a defterekben leírt nevek nem mindig teljesen követik az eredeti nyelvformát és olvasatukba is csúszhattak be hibák (a török írásjelek különböző hangokat jelölhetnek) - hanem mert a népesség nemzetiségét a családnevek alapján nem lehet pontosan, számszerüen kifejezni” (DÁvID 1993: 11).
} 
Szempontok és módszerek a személynév és etnikum összefüggésének...

ahányan szlovák eredetű nevet viselnek. Az eltérések az egyéb kategóriában szereplő bizonytalan etimonú nevek megfejtésével bizonyára csökkenthetők lennének.

1. táblázat: Somogy vármegye 1744. évi inszurgens lovasságának anyanyelve és családnevük eredet szerinti megoszlása ${ }^{8}$

\begin{tabular}{|l|c|c|c|c|c|}
\hline \multirow{2}{*}{} & \multicolumn{2}{|c|}{ Anyanyelv } & \multicolumn{2}{c|}{ Családnéveredet } & Eltérés \\
\cline { 2 - 6 } & Adat & \multicolumn{1}{c}{$\%$} & Adat & \% & \% \\
\hline Magyar & 78 & 76,47 & 74 & 72,55 & $-3,92$ \\
\hline Német & 2 & 1,96 & 2 & 1,96 & 0,00 \\
\hline Horvát & 12 & 11,76 & 15 & 14,71 & $+2,95$ \\
\hline Szlovák & 10 & 9,80 & 5 & 4,90 & $-4,90$ \\
\hline Egyéb & - & - & 6 & 5,88 & $+5,88$ \\
\hline Összesen & 102 & 100,00 & 102 & 100,00 & 0,00 \\
\hline
\end{tabular}

A vizsgálat további tanulsága, hogy ha az egyes eseteket nézzük, akkor azt látjuk, hogy például a Horváth családnevüek közül négyen magyar, hárman pedig horvát nyelvünek vallották magukat. Pintér Pál szlovák, Molnár János és Kovács János horvát, míg Szedlák György, Subassics György, Gyurinecz Márton a magyar nyelvüek között szerepel. Megállapítható tehát, hogy ,individuális vizsgálatokra a névelemzés valóban alkalmatlan. Ha azonban a statisztikai sokaságot vizsgáljuk, akkor az ilyen »hibák « kioltják egymást." A regionális vizsgálatoknál nagy mennyiségű adat esetében az alkalmazott névelemzés DEMETER GÁBOR szerint használható (DEMETER 2009: 6). ${ }^{9}$

DEMETERék a nevek azonosításában a korábbi népiségtörténeti iskola módszerét (1. fenn) követték, de például a népnévi eredetü családneveket nem a bizonytalanok közé, hanem a közszói jelentésüknek megfelelő kategóriába sorolták. „Tóth István például lehet magyar identitású, neve alapján mégis a szlávok közé került besorolásra - holott Szilágyban nem sok szláv élt. Erre a magyar nemzetiségüek túlbecslésének elkerülése érdekében volt szükség: így a magyarok számát 6-10\%-kal is redukálhattuk, ennyi volt a szláv vezetéknevüek aránya." (DEMETER-BAGDI 2009a: 28.)

A másik eltérés a keresztnevek felhasználása terén mutatkozik. „Az 1715-ös összeírás esetében számos alkalommal találkozhatunk magyar család- és román keresztnévvel. Ezeket a személyeket, akik zömmel görögkatolikusok voltak, anyanyelv szempontjából románnak tekintettük: Ion Csordás, Kihor Sipos, Kosztin Sánta, Teodor Fekete, Teodor Bíró, Teodor Ravasz. Álláspontunk szerint a vallási alapon adott keresztnév hordozza az aktuális identitást, míg a családnév a korábbi identitásra - a felmenőkére - utal" (DEMETER-BAGDI 2009b: 13; kiemelés tőlem). „Más esetekben a név alapján - pl. Lakatos Mihály, Pap Dániel (Sz.solymos) - nem sorolható be a személy az egyik csoportba sem teljes bizonyossággal, hiszen románok között ugyanúgy előfordulhatnak ilyen nevek (Mihai Lacatus, Daniel Pop), mint a magyarok között” (DEMETER-BAGDI 2009a: 28).

\footnotetext{
${ }^{8}$ Az adatok forrása: DEMETER 2009: 6.

${ }^{9}$ Hasonló megállapításra jutott SZENTGYÖRGYI RUDOLF is a 17. századi boszorkányperekben szereplő személyek neve és megnyilatkozásaik tanulmányozásakor (2012).
} 
A történeti demográfiai elemzések tehát - ugyan különböző mértékben és módszert követve - alkalmasnak tartották/tartják a személyneveket egy terület etnikai összetételének a feltárásához azokban az időszakokban, amelyekből más (az etnikumra egyértelmübben utaló) források még nem állnak rendelkezésünkre. Tapasztalataik, meglátásaik és módszereik bizonyos elemei nem hagyhatók figyelmen kívül egy nyelvészeti alapú etnikai rekonstrukciós modell kidolgozása esetén sem.

4. A személynévi alapú etnikai rekonstrukció egy lehetséges módszeréről. A kutatástörténeti áttekintés után a továbbiakban rátérek a személynévi alapú etnikai rekonstrukció többszintes modelljének bemutatására. A módszer abban tér el a történettudományi előzményektől, hogy igyekszik szétválasztani a néveredet meghatározását az etnikai hovatartozástól, külön szinten helyezve el az egyes vizsgálati célokat. (1) Az első szinten kizárólag a nyelvészeti szempontok figyelembevételével, az etimológiai és névtani kutatás szabályai szerint történik meg a családnéveredet meghatározása, a név nyelvi hátterének feltárása. ${ }^{10} \mathrm{Az}$ így kapott eredmény a nyelvtudomány, illetve a névtan számára önmagában is értékelhető, és fontos alapot jelent a további nyelvészeti és névtani vizsgálatokhoz. Az interdiszciplináris tudományos igény azonban nem teszi megkerülhetővé annak az egyértelmüsítését, hogy a nyelvi adatok felhasználhatók-e egyáltalán a Kárpátmedence etnikai összetételének vizsgálatában, és ha igen, milyen módszer alapján. (2) Az etnikai rekonstrukció vizsgálati szintjének két, egymásra épülő (szorosabban vett névtani és interdiszciplináris alapú) részét különítem el. (2a) Az előbbi esetben az egyénnevek (keresztnevek, referáló nevek) tanulságait vesszük alapul, (2b) a második esetben pedig azokat az egyéb információkat, amelyek közvetlenül vagy közvetve az etnikai háttérre utalnak.

4.1. A családnevek nyelvi eredete. A családnevek nyelvi hovatartozásának (eredetének) a nyelvészeti-névtani vizsgálata számos olyan kérdést és szempontot vet fel, amelyek alapvetően befolyásolhatják a kapott eredményeket. A névanalízis (már korábban is érintett) korlátai mellett mindenekelőtt a névélettani, névszociológiai és névpragmatikai kritériumok érdemelnek kiemelt figyelmet a nyelvi-etnikai rekonstrukciós forrásérték megállapításakor. E szempontok között említhető például a lejegyzési mód, a fennmaradási forma, a lejegyző személye és a névhasználati gyakorlat. A probléma összetett és szerteágazó volta miatt részletes elemzésre ezúttal nem vállalkozhatok, itt csupán néhány, a témához szorosan kapcsolódó szempontot kívánok kiemelni.

A családnevek nyelvi rekonstrukciójában módszertani szempontból két alapvető mozzanatot tudunk elkülöníteni: az egyik az adat nyelvhez kapcsolása, a másik a névetimon meghatározása. A kettő általában szorosan összefügg, időben is egyszerre történik. Vannak azonban olyan esetek, amikor a nyelvi azonosítást a pontos etimológiai magyarázat nem feltétlenül követi vagy elözi meg. Ez azt jelenti, hogy úgy kapcsoljuk a családnevet egy adott nyelvhez, hogy a név pontos etimológiai magyarázatával, illetve az erre épülő névadási háttér feltárásával adósak maradunk. Az utóbbi főként az idegen

\footnotetext{
${ }^{10}$ Vö. „Az etnikai célú nyelvi rekonstrukció legfőbb eszköze maga a helynévetimológia, amely eredendően arra kíváncsi, hogy a név milyen nyelvi közegben jött létre” (HofFMANN 2007: 14).
} 
eredetű nevek azonosításakor alkalmazott, általános eljárás. A nagy névadatbázisok elemzésekor az egyenkénti névfejtés rendkívül időigényes kutatómunkája helyett olyan sajátosságokat kell segítségül hívnunk, amelyekkel pontos etimon ismerete nélkül is meghatározható a név nyelvi háttere. Erre a legjobb példát a nyelvspecifikus morfológiai kritériumok szolgáltatják. Közismert, hogy bizonyos névformánsok meghatározott nyelvek családneveinek létrehozásában vesznek részt (pl. az -er német, az -ul/-uj román, a -sky szláv ${ }^{11}$ ). Ezek általában a nyelvhasználók számára is felismerhetőek, a laikus nyelvietnikai kategorizáció alapjául szolgálhatnak (vö. SLÍZ - P. TÓTH - FARKAS 2018: 44-46). Szintén használható eljárás a fonetikai-fonológiai és lexikális sajátosságok figyelembevétele. A fonémaállomány esetében például a névben szereplő palatális labiális magánhangzók kizárják a román vagy szláv eredetet. Továbbá bizonyos gyakori névelemek (pl. német -man[n], -berg) és fonémakombinációk (pl. német -nkl-, -ing-, szláv -ina-) szintén segítik a nyelvi azonosítást. Természetesen ez az eljárás sem abszolút érvényü, szükséges a kódolás utólagos ellenőrzése. Részben ezt a tulajdonságot használják ki az újabb személynévelemző programok is (pl. MATEOS 2007, LEE et al. 2017; 1. még FARKAS 2015, VÖRÖS 2016).

Minden névanyagban vannak olyan nevek, amelyek egyfajta interlingvális ,homonimaként" egyszerre több névrendszerben is jelen vannak. Magyar és szláv (szlovák) megfelelések például a Kovács $\sim$ Kováč, Mocsár Močiar, Bojtár $\sim$ Bojtár, Horvát $\sim$ Horvat, Kocsis Kočis, Gazda Gazda, Szabó Sabov/Sabol, Fullajtár Fulajtár stb. (vö. KNIEZSA 1934/1965/2003: 348-349). Azokban az esetekben, amikor a helyesírás nem segít az egyes nevek nyelvekhez kapcsolásában (sajnos ilyenek az adóösszeírások is), e nevek kategorizációja a következőképpen történhet: 1. megadjuk az összes figyelembe vehető magyarázati lehetőséget (pl. a Kovács $\sim$ Kováč magyar és szláv minősítést is kap), vagy 2. az összes előfordulást a bizonytalan eredetü nevek kategóriájába soroljuk, ${ }^{12}$ vagy 3. a települési (esetleg járási) többségi arányok szerint adjuk meg a többes besorolású nevek eredetét.

Nézzük meg röviden ezek mindegyikének az elönyeit és hátrányait. Az első esetben az összes lehetséges magyarázatot megadva járunk el, figyelembe véve annak a lehetöségét is, hogy az egyik névelőfordulás az egyik nyelvből, a másik a másikból eredeztethető. Így viszont a statisztikai számításnál az arányok torzulására lehet számítani a többes besorolású nevek többszöri felvétele miatt (erre 1. pl. N. FODOR 2010: 92-94). A második esetben nem vállaljuk a valószínüsíthető névetimonnak az adott névelőforduláshoz való kapcsolását, hanem a bizonytalan nevek közé soroljuk ezeket az eseteket is. Ennek

\footnotetext{
${ }^{11}$ A szláv nyelvi adatok belső elkülönítése, egyes szláv nyelvekhez rendelése szlavisztikai ismeretek nélkül minden kétséget kizáróan nem végezhető el, ennek hiányában csupán a szláv gyüjtönév alá tudjuk rendelni a névadatokat. A TMCsA. névanyagának elemzésekor magam is ezt a szükségszerü megoldást alkalmaztam. (Hasonló eljárásra 1. VöRÖS 2018 is.) AcsÁDYnál (1896) a szláv nyelvek két csoportra osztva: „tót vagy rutén” és „szerb-horvát” kategóriában találhatók.

${ }^{12}$ Ennek a megoldásnak egyfajta altípusaként lehet említeni VöröS FERENC (2018) eljárását, miszerint a többes besorolású nevek arányait külön-külön csoportban adja meg, így a déli területek névanyagának alaktani sajátosságaira épülő elemzésében magyar, szláv, német, német-magyar és szláv-magyar csoportokat különít el.
} 
a nyelvészeti szempontból szintén indokolható eljárásnak azonban az a hátránya, hogy bizonyos produktív családneveket kihagyva a számításból nem feltétlenül kapunk hiteles számokat például a családnévtípusoknak a névanyagban képviselt arányáról. ${ }^{13}$ Harmadik megoldásként, úgy vélem, nincs okunk bizonytalannak minősíteni azokat a neveket, amelyeknek a nyelvi környezete egyértelműen meghatározható, azaz az etnikailag homogénnek tekinthető területeken azt a magyarázatot kell figyelembe vennünk, amely a többség nyelvi eredetével megegyező. Saját számításaim szerint például a feldolgozott adóösszeírások szerint Trencsén megye családneveinek 94\%-a szláv nyelvi hátteret mutat a vizsgált időszakban, csupán elvétve találunk német és magyar eredetü neveket, 2-2\% körüli arányban. Nyilvánvalóan ebben az esetben a 65 trencséni Kovács családnévnek a szláv eredetủ nevek közé sorolása könnyen indokolható, főként ha az előfordulások helyeire (településekre) lebontva is megvizsgáljuk a kérdéses nevek környezetét. Így ugyanis még egyértelmübb kategorizáció végezhető el: például a Trencsén megyei Sztranszki nevü település 22 családnévi adata szláv eredetủ, ebböl következően a 23. névelőfordulásnak, a Kovács-nak a szláv nyelvi kategóriához való kapcsolása sem lehet kérdéses. Hasonlóan járunk el más (pl. német, román, magyar) nyelvi közegben felbukkanó többes besorolású családnevek esetében is. ${ }^{14}$ A módszer alkalmazhatósága mellett szól az előbbi megoldásoknál jóval kisebb aránybeli eltérés (hibahatár) is. ${ }^{15}$ További problémát a vegyes lakosságú területek neveinek etimológiai minősítése okoz, hiszen például a nyelvhatár sávjában vagy a vegyes lakosságú falvakban a többféle nyelvi magyarázati lehetőséggel bíró neveket (egyéb információ híján) nagyon nehéz egyik vagy másik nyelvhez kötni. E nevek ezért szükségszerüen az etimológiai minősítéskor (kódolásnál) megkapják az összes lehetséges magyarázat kódját, viszont az etnikai minősítésük bizonytalan lesz.

További problémát eredményeznek a különböző adóösszeírásokban tapasztalható névtorzulások, névfordítások és névmegfeleltetések esetei is. A párhuzamos összeírások példái azt mutatják, hogy olykor az összeírást végző megbízott a számára ismeretlen nevet saját anyanyelvi kompetenciája szerint alakítja át: 1. ,értelmesíti” (pl. Drobus $>D a$ rabos, Brad > Baráth); 2. (föként a keresztnevek, illetve a keresztnévi eredetủ családnevek esetében) a saját anyanyelvének megfeleltethető névalakkal helyettesíti (pl. Blas > Balázs,

${ }^{13}$ Az 1721-1722-es erdélyi adatokkal részben kiegészített 1720-as magyarországi adóösszeírás névadatbázisában leggyakoribb névként szereplő Kovács családnévlemma például 3340 adattal a teljes névanyag 1,78\%-át teszi ki. A többféleképpen eredeztethető nevek aránya együttesen elérheti akár a 10\%-ot is. Ez elég magas arány ahhoz, hogy a következtetések nagy hibahatárát eredményezzék. Többek között erre hivatkozva nem tartotta megfelelö eljárásnak DÁvID ZOLTÁN a bizonytalan nevek kategóriájának elkülönítését (1. fenn).

${ }^{14} \mathrm{Az}$ ismertetett módszer kapcsán párhuzamot lehet vonni azzal a helynévrekonstrukciós eljárással, amely szerint az adathoz kapcsolható különbözö nyelvi magyarázatok közötti döntést névföldrajzi, névszociológiai és névtipológiai stb. szempontok figyelembevétele segítheti (vö. HOFFMANN-RÁCZ-TÓTH 2018: 461).

${ }^{15}$ Itt arra gondolunk, hogy ha az így minősített nevek között mégis lennének a belső migráció révén a korábbi névadó közegtől eltérő nyelvi környezetbe kerülő családnevek, ez fordítva is feltételezhető, így a teljes anyag esetében a végső arányokat a plusz-mínusz eltérések nem befolyásolhatják számottevő mértékben (hasonló véleményre 1. DEMETER 2009: 6). 
Mihaila > Mihály, Moka Sziminik > Simon Moka); 3. „lefordítja” (pl. Erdellan Juon > Erdélyi János, Albus Juvon > Fehér Jancsi) (1. bővebben N. FODOR 2015a, 2015b; SLíz 2014, 2017: 142-157). Az utóbbi esetében nem zárhatjuk ki a párhuzamos személynévadást, illetve névhasználatot sem, de ezek csak a vegyes lakosságú falvakban szolgálhatnak magyarázatul.

A szakirodalomban háromféle magyarázat született erre a jelenségre. Ezek szerint a Mlynár Molnár, Erdellan Erdélyi stb. típusú névpárok a két- vagy többnyelvü közegben 1. egymástól függetlenül, de azonos szemlélet alapján keletkeztek; 2. az egyik név másodlagos, a névadó etnikum által korábban létrehozott név másik nyelvnek megfeleltetett, természetes fordítása; 3. a lejegyző írnok által, az élőnyelvben használt név alapján tükörfordítással kreált, a valóságban nem létező név. (A párhuzamos személynévadás problematikájának legutóbbi összefoglalását 1. То́тН 2016: 69-71.) A kérdés azért is lényeges, mert alapvetően megkérdőjelezheti bizonyos források (pl. a tárgyalt conscriptiók) megbízhatóságát a nyelvi és föként az etnikai rekonstrukciós elemzésekben. Általában arra hivatkozva szokták bizonyos (föként környező országokbeli) kutatók elvetni az összeírások felhasználhatóságát, hogy a magyar anyanyelvű írnokok a saját anyanyelvükre fordították le a nem magyar családneveket. SLÍz MARIANN ugyanakkor a hazai, középkori német és cseh nyelvü oklevelekben talált olyan, vélhetően magyar etnikumú személyeket, akiknek családnevét németül vagy csehül rögzítették a scriptorok (SLíz 2017: 135-140). A jelenség tehát nem kizárólag magyar sajátosság volt, és semmiképpen sem volt mögötte az etnikai arányok tudatos eltorzításának a szándéka. Azt, hogy ez az eljárás inkább szórványosnak tekinthető, jól igazolja az is, hogy számtalan nem magyar családnév került be ennek ellenére az összeírásokba, illetőleg sok esetben a keresztneveket is az élő nyelvi alaknak megfelelően rögzítették a latinosítás általános szokása és gyakorlata ellenére. ${ }^{16}$

Le kell szögeznünk, hogy az adóösszeírások készítésének célja az adózó népesség minél teljesebb körü felmérése volt, melyhez alapelvként szorosan kapcsolódott a személyek későbbi azonosíthatóságának igénye és szükségszerüsége. Így ez a jogi műveleti jelleg - egyes vélemények szerint - ,aligha tette megengedhetővé, hogy az adózó azonosítására [...] »konstruált«, fiktív nevet rögzítsenek" (TÓTH 2016: 69; 1. még KÁZMÉR 1981: 46 is). Véleményem szerint azonban joggal feltételezhetjük, hogy bizonyos névhiányos

\footnotetext{
${ }^{16}$ A Szabo Gabrilla, Madarászi Ignát, Mihály Grigori, Piros Toma, Gyarmaty Petrul stb. nevek példái mutatják, hogy az írnokok sokszor a könnyen fordítható egyénneveket is változatlanul megtartották. Ezekben az esetekben az, hogy a magyar családnevek fordítás eredményei lennének, teljesen kizárható. Az erdélyi összeírásokban jóval ritkábban előfordulhatott természetesen az is, hogy az egyénnevek ,uniformizálása” nem latinul, hanem magyar nyelvi megfelelőik alapján történt (leggyakrabban például a János, György, Simon, Mihály és Demeter esetében). Ezek a keresztnevek magyar családnévvel együtt állva valóban csak korlátozottan, egyéb tényezők (pl. a névkörnyezet) ismeretében lehetnek alkalmasak az etnikai háttér meghatározására a vegyes lakosságú területeken.
} 
esetekben ${ }^{17}$ éppen az azonosíthatóság érdekében maga az összeíró alkotott megkülönböztető nevet az elnevezett etnikuma (pl. Oláh), foglalkozása (pl. Késcsináló) vagy a társadalmi státusza (pl. Szabados) alapján. Nyelvi szempontból az ilyen nevek minősítése nem térhet el a tényektől, viszont a név mögötti valóságos etnikai hovatartozás megállapításakor a fenti információkat már nem hagyhatjuk figyelmen kívül.

A családnevek etimológiai elemzésén alapuló számítások lehetővé teszik az adatok térképes megjelenítését. A TMCsA. 1715-ös magyarországi, Erdély bizonyos 1713-as adataival kibővített adatbázisából az alábbiakban a magyar, szláv és német eredetü családnevek területi kiterjedését mutatom be (1-3. ábra). (Ezúttal a háttéradatok közlésétől és a részletes elemzéstől terjedelmi okokból eltekintek.)

1. ábra: Magyar eredetü családnevek területi megoszlása a Kárpát-medencében a 18. század elején (járási felosztás) (TMCsA. 1713-1715)

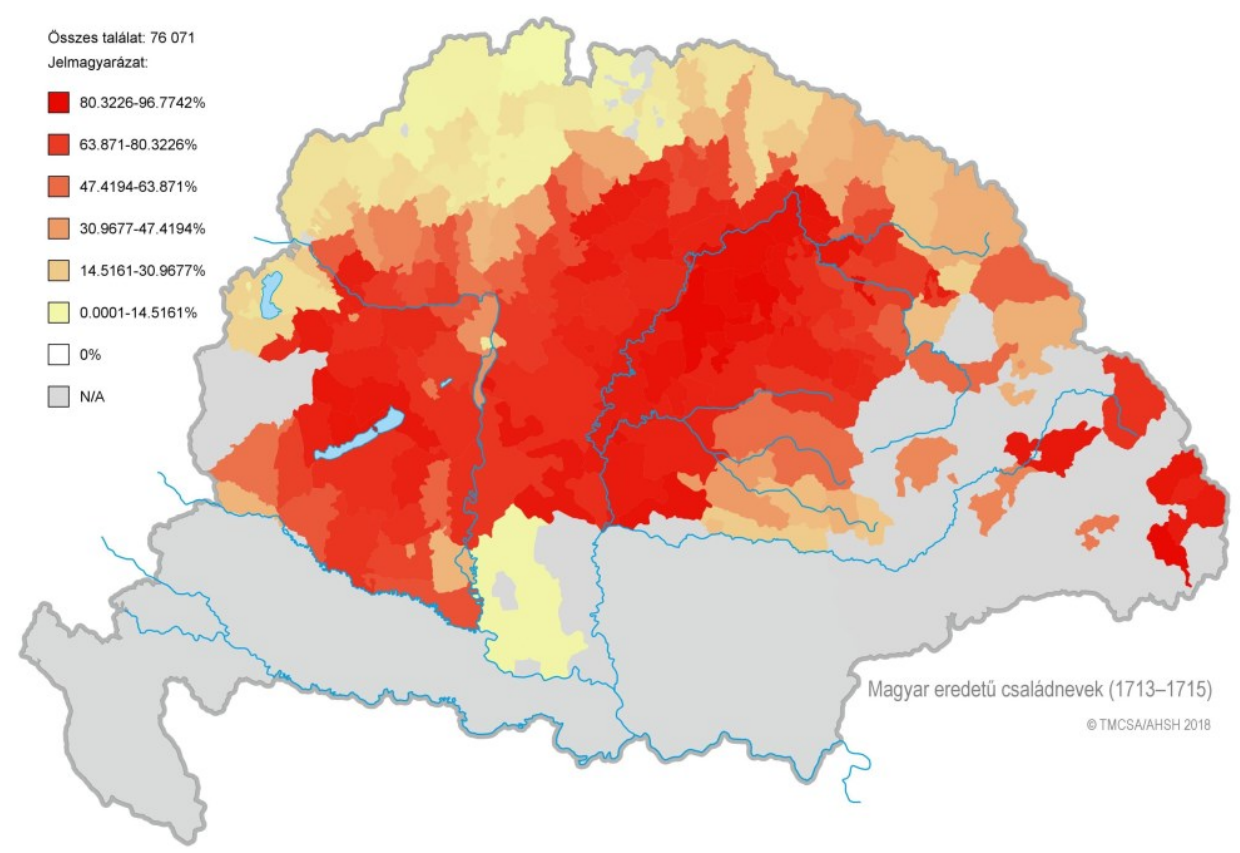

${ }^{17}$ A 18. század eleji erdélyi adatok azt mutatják, hogy a románoknak - főként a Moldvából és Havasalföldről újonnan betelepülőknek - még nem minden esetben volt családnevük (bővebben 1. N. FODOR 2016). 
2. ábra: Szláv eredetű családnevek területi megoszlása a Kárpát-medencében a 18. század elején (járási felosztás) (TMCsA. 1715)

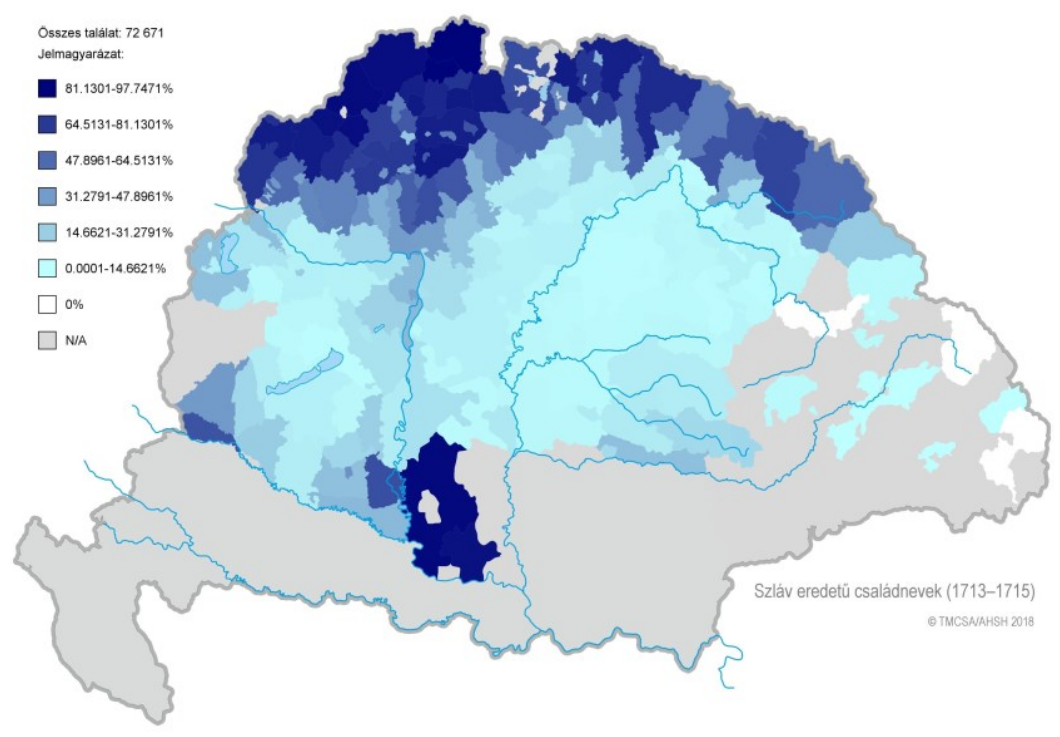

3. ábra: Német eredetủ családnevek területi megoszlása a Kárpát-medencében a 18. század elején (járási felosztás) (TMCsA. 1715)

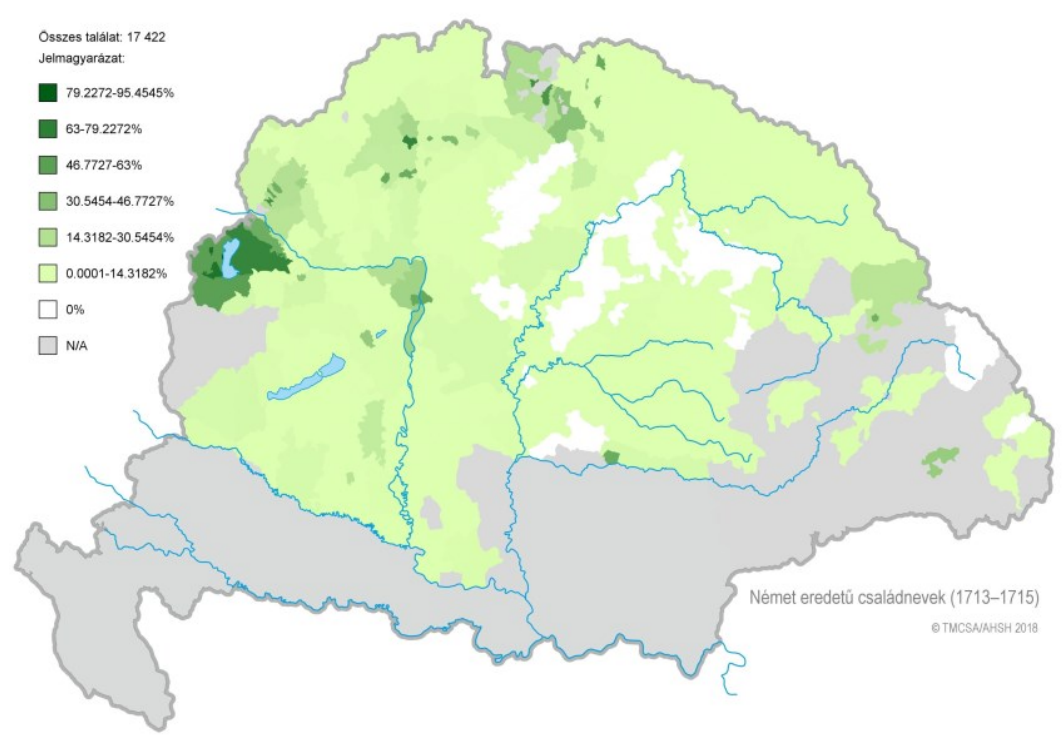


4.2. A felekezetspecifikus keresztnevek és egyéb források tanulságai. Az ismertetett, személynévi alapú etnikai rekonstrukciós eljárás második szintjén a keresztnévanyag tanulságainak feltárása és felhasználása történik. Az egyénnévhasználat szorosan összefügg nyelvi, vallási, nemzeti, földrajzi, antropológiai, migrációs, regionális és egyéb kulturális identitásokkal, amelyek befolyásolják az egyéni nevek szülők általi választását (vö. MATEOS 2014: 40). Éppen a „kulturális lenyomat” miatt tartják többen is alkalmasnak az egyénneveket az etnikai és migrációs célú vizsgálatokhoz (vö. FARKAS 2015). Történeti és Kárpát-medencei aspektusban azt mondhatjuk, hogy a felsorolt tényezők közül a nyelv mellett leginkább a vallás hagy nyomot a névhasználaton. Elsődlegesen a nyugati és a keleti egyház névadási gyakorlata között húzódik látható választóvonal (vö. DEMETER-BAGDI 2009b: 13). A nyugati kereszténységhez tartozó felekezetek névadási szokásaiban főként névgyakoriság alapján érzékelünk különbséget, míg a keleti egyház nevei a kétféle névanyagban kimutatható átfedések (közös elemek) mellett markáns eltéréseket is hordoznak.

A névanalízis komplex módszerét a továbbiakban a TMCsA. Erdélyre vonatkozó adatbázisából vett példákkal mutatom be. A Kárpát-medencei névrendszerek közötti évszázados kölcsönhatásra a soknemzetiségü Erdély névanyaga számos példát szolgáltat, ezért a módszer teszteléséhez a régió négy, különböző etnikai összetételü területi egységének a tanulságait hívom segítségül. ${ }^{18}$

Besztercevidék és a Királyföldhöz tartozó Köhalomszék jelentős szász népességgel rendelkezett, míg Torda területén a román, Belső-Szolnok vármegyében pedig a magyar lakosság lehetett a legnagyobb számú a 18. század elején. Míg a magyarok és a románok jelenléte mindegyik vizsgált területen jelentős, addig a németeké az utóbbi két helyen elenyésző volt, többséget a szász kiváltsággal bíró területen sem adtak (1. részletesen a 2. és 3. táblázat adatait).

2. táblázat: Családnévetimonok eredet szerinti megoszlása (1713)

\begin{tabular}{|l|r|r|r|r|r|r|r|r|c|}
\hline & \multicolumn{2}{|c|}{ Magyar } & \multicolumn{2}{c|}{ Román } & \multicolumn{2}{c|}{ Német } & \multicolumn{2}{c|}{ Egyéb } & Összesen \\
\cline { 2 - 10 } & Adat & \multicolumn{1}{c}{$\%$} & Adat & $\mathbf{\%}$ & Adat & $\mathbf{\%}$ & Adat & \% & Adat \\
\hline Belső-Szolnok & 337 & 59,33 & 218 & 38,38 & 3 & 0,53 & 10 & 1,76 & 568 \\
\hline Besztercevidék & 984 & 32,93 & 1117 & 37,38 & 740 & 24,77 & 147 & 4,92 & 2988 \\
\hline Kőhalomszék & 1156 & 51,91 & 232 & 10,42 & 662 & 29,73 & 177 & 7,95 & 2227 \\
\hline Torda & 829 & 46,16 & 848 & 47,22 & 14 & 0,78 & 105 & 5,85 & 1796 \\
\hline Összesen & $\mathbf{3 3 0 6}$ & $\mathbf{4 3 , 6 2}$ & $\mathbf{2 4 1 5}$ & $\mathbf{3 1 , 8 6}$ & $\mathbf{1 4 1 9}$ & $\mathbf{1 8 , 7 2}$ & $\mathbf{4 3 9}$ & $\mathbf{5 , 7 9}$ & $\mathbf{7 5 7 9}$ \\
\hline
\end{tabular}

${ }^{18}$ A felhasznált források hivatkozása: Magyar Nemzeti Levéltár Országos Levéltára F 49. 4/7. Belső-Szolnok Alsó járás; 5/15. Kőhalomszék; 4/2. Torda Alsó járás; 5/14. Besztercevidek. A forrásanyag digitalizálása és elektronikus rögzítése az NKFIH 116414. számú szerződése támogatásával készült. 
Szempontok és módszerek a személynév és etnikum összefüggésének...

3. táblázat: Etnikai arányok az egyénnevek alapján (1713)

\begin{tabular}{|c|c|c|c|c|c|c|c|c|c|}
\hline & \multicolumn{2}{|c|}{ Magyar } & \multicolumn{2}{|c|}{ Román } & \multicolumn{2}{|c|}{ Német } & \multicolumn{2}{|c|}{ Egyéb } & \multirow{2}{*}{$\begin{array}{c}\text { Összesen } \\
\text { Adat }\end{array}$} \\
\hline & Adat & $\%$ & Adat & $\%$ & Adat & $\%$ & Adat & $\%$ & \\
\hline Belső-Szolnok & 293 & 51,58 & 270 & 47,54 & 1 & 0,18 & 4 & 0,70 & 568 \\
\hline Besztercevidék & 857 & 28,68 & 1327 & 44,41 & 734 & 24,56 & 70 & 2,34 & 2988 \\
\hline Kőhalomszék & 1102 & 49,48 & 319 & 14,32 & 691 & 31,03 & 115 & 5,16 & 2227 \\
\hline Torda & 721 & 40,14 & 1050 & 58,46 & 2 & 0,11 & 23 & 1,28 & 1796 \\
\hline Összesen & 2973 & 39,23 & 2966 & 39,13 & 1428 & 18,84 & 212 & 2,80 & 7579 \\
\hline Eltérés ${ }^{19}$ & & $-4,39$ & & $+7,27$ & & $+0,12$ & & $-2,99$ & \\
\hline
\end{tabular}

4.2.1. Az erdélyi adóösszeírások lejegyzői a névaláírásuk és a szöveges településleírások nyelve alapján többnyire magyar etnikumúak voltak, vagy legalábbis tudtak magyarul. A nevek feljegyzésekor azt az általános gyakorlatot követték, hogy a magyarok és a németek keresztnevét latinosított (ritkábban anyanyelvi) alakban, míg a románokét többnyire eredeti (élőnyelvi) román formájukban (ritkábban magyarul) jegyezték fel. Az élőnyelvi névalak írásbeli rögzítése nyilván összefügg azzal a tényezővel, hogy a latin nyelvi megfeleltetés az írnok számára nem volt mindig magától értetődő és egyszerü az ortodox és a görögkatolikus keresztnevek esetében. ${ }^{20}$

A fenti eredmények egyértelmüen jelzik az elemzési módszer kétféle számítása közötti aránybeli eltéréseket (vö. 2. és 3. táblázat, ill. 1. a 3. táblázat utolsó sorában). Míg a magyar eredetü családnevek a vizsgált anyagban 43,62\%-os arányt, addig a keresztnevek nyelvi eredete alapján kikövetkeztetett etnikai arány már csak 39,23\%-ot mutat, azaz a magyar eredetü családnevek átlagosan 4,39\%-a mellett nem magyar keresztnév áll. A román keresztnevek viszont a családnévetimonhoz képest 7,27\%-os többletet mutatnak, amely a magyar és a bizonytalan családnevek csoportjából adódik össze. (A német néveredet és az etnikai rekonstrukció számadatai között jelentős eltérés nem tapasztalható a fenti számítás szerint.) Az etnikai rekonstrukció tanulsága, hogy a román etnikum feltételezett jelenléte a vizsgált megyékben a magyarságéhoz hasonló arányt (39,13\%-ot) jelez a nyelv- és vallásspecifikus keresztnevek alapján. A magyar családnév + román keresztnév kombináció létrejötte mögött a már fent említett okok (asszimiláció, az írnok „magyarítása”) mellett egy harmadikat is meg kell említenünk. Egy kétnyelvü környezetben sokszor a feltett kérdés nyelve dönti el a névhasználatot, ezért bizonyos esetekben nem alaptalan azt feltételeznünk, hogy a magyar nyelvü írnokok a kétnyelvű nyelvhasználók kérdésre adott spontán névfordításait jegyezték fel „hiteles” névadatként (vö. DEMETER 2014: 85). Ez is növelhette a magyar családnevek arányát.

Ha megnézzük az egyes területi egységeket, akkor azt látjuk, hogy a magyar családnevekhez képest a magyar etnikum feltételezett számaránya mindenhol 2,43-7,75\% közötti

${ }^{19}$ A családnévetimonok eredet szerinti megoszlása és az etnikumspecifikus keresztnevek segítségével kikövetkeztetett etnikai arányok közötti eltérés.

${ }^{20}$ Tipikus román egyházi keresztnevek (forrásbeli helyesírással): Togyer, Illia, Aleksza, Vállyán, Onesztin, Pintye, Onya, Vaszij, Iszai, Jonask, Kosztin, Marian, Akim, Makavej, Timote, Flore, Nuczul stb. 
mértékü csökkenést mutat. Torda megye adatainál a csökkenés megközelíti a 8\%-ot, ami már elég jelentősnek mondható; ugyanitt a románok aránya 11,4\%-kal nőtt a névetimonhoz képest.

Az anyanyelvi alakú (nem latinosított) keresztnevek tehát segítségünkre lehetnek az aktuális nyelv (identitás?) feltárásában. Sajnos a 18. század eleji összeírások esetében ezzel a módszerrel csak az adatok egy kisebb hányadában tudunk élni, mert az esetek nagy részében a kor hivatalos írásbeliségének megfelelően az egyénneveket latin alakjukban rögzítették, így élőnyelvi-etnikai szempontból semlegesekké váltak. Ebben az esetben sem kell azonban feltétlenül a keresztnevek tanulságairól lemondanunk, hiszen bizonyos nevek gyakorisága nyelvspecifikus sajátosságot hordozhat. Eltérö lehet ugyanis két nyelv referáló vagy listaneveinek összetétele akkor is, ha történetesen ugyanazon felekezethez tartoznak (erre 1. pl. N. FODOR 2014: 35-38). ${ }^{21}$ Ez az eltérés pedig a különböző kulturális jegyek hagyományozódásával magyarázható.

4.2.2. Az így kapott arányok kétségtelenül már hitelesebb és árnyaltabb képet rajzolnak a feltételezett etnikai megoszlásról, mint ha erre pusztán a családnévetimonokból akarnánk következtetni, de a tényleges etnikai megoszlásról teljes bizonyosságot továbbra sem adnak. Az etnikai rekonstrukció következő lépéseként szükséges (amennyiben a forrás lehetővé teszi) az egyéb adatokat és a névszociológiai tényezőket is figyelembe venni. Az ehhez kapcsolódó eljárást az alábbi példával illusztrálom.

A szász kiváltságokkal rendelkező Kőhalomszéken található Halmágy településen 1713-ban 95 személyt írtak össze, akiket két társadalmi csoportba soroltak: „,[Nomina] incolarum" 'lakosok [neve]', ,,valachi”' 'oláhok'. Az előbbi csoportban 89, az utóbbiban 6 személy szerepel. ${ }^{22} \mathrm{Az}$ adófizető lakosok családnevei között mindössze két nem magyar eredetű található (a román Moldován és a német Gotsman) 3 előfordulással. A többi családnév kétségtelen magyar eredete alapján joggal következtethetünk arra, hogy a népes település lakosságának döntő többségét a magyarok adták a 18. század elején. A magyar nevüek között feltünő, velük egy társadalmi rétegbe sorolt idegen eredetü családnevek viselőiről pedig azt feltételezhetjük, hogy már asszimilálódtak a magyar többséghez. Erre utal az is, hogy keresztnevük (Johannes, Stephanus, Michaelis) ugyanúgy latinosított alakban szerepel a forrásban, mint a magyaroké. ${ }^{23}$ Az etnikai jelleg kiemelésével megkülönböztetett új lakosok nevei azonban teljesen román névalakban lettek feljegyezve. Tehát a települési szintü mikrovizsgálat során olyan tényezők (társadalmi állás, etnikumra történö

${ }^{21}$ Pl. a német keresztnevek gyakorisági listájában a Christianus 169, Tobias 87, Fridericus 63 , Ferdinandus 51 előfordulással az első 30 között szerepel, míg a magyar listában alig van néhány bizonytalan adatuk (1-10 előfordulás).

${ }^{22}$ Halmágy családnevei 1713-ban (az előfordulás számával): Török 10, Jakab 8, Geréb 7, Demeter 5, Szabó 4, Gergely 4, Zilahi 4, Bakó 4, Benkö 4, Lukács 3, Fogarasi 3, Márkus 2, Kádár 2, Pap 2, Orbán 2, Kelemen 2, Bálint 2, Lokodi 2, Barta 2, Varga 2, Kis 2, Moldován 2, Balog 1, Antal 1, Andor 1, Balázs 1, Boldizsár 1, Csoba 1, Kerekes 1, Pál 1, Benedek 1, Gotsman 1, Szücs 1. Valachi: Many Boras, Juon Livoje, Joun Kota, Bukur Rusalja, Raduly Olah, Sztan Komsa.

${ }^{23}$ Ez az eljárás a DÁVID ZOLTÁN által alkalmazott általános etnikai rekonstrukciós módszerrel mutat rokon vonásokat, melynek alapja nem az egyén, hanem a település etnikai vetülete (1. fenn). 
közvetlen utalás stb.) is figyelembe vehetők, amelyek a családnevek etimológiai és az egyénnevek etnikai rekonstrukciós célú elemzésével sem válnak nyilvánvalóvá.

A vizsgált anyag 7434 névadatában azonban mindössze 243 személynél (3,27\%) találunk etnikumra történő utalást („Valachi”, „Oláh”, „Oláh Lakos”). Tanulságos azonban, hogy közöttük csupán hat olyan személy van $(2,47 \%)$, akinek a személyneve ellentmond az etnikai minősítésnek. ${ }^{24}$ A többi esetben a családnévetimon, a keresztnév nyelvi alkata vagy mindkettő együttesen alátámasztja és visszaigazolja az etnikai besorolás helyességét, és egyúttal a módszer alkalmazhatóságát is.

A társadalmi kategorizáció sokszor konkrét etnikai utalás nélkül is segítségünkre lehet. Erdélyben például általánosan jellemző bizonyos területeken, hogy az alsóbb társadalmi rétegekhez tartozók (pl. zsellérek, csavargók), illetve egyes foglalkozásokat üzők (pl. pásztorok) között nagyobb számban találunk román nevüeket, mint az adófizető jobbágyok vagy a szász és székely székek kiváltságos tagjai között (vö. N. FODOR 2016). Ennek az ismerete is hozzájárulhat a bizonytalan nevek azonosításához.

Számos tanulságot hordoznak az etnikai hovatartozás feltárásában azok a nem összeírás jellegü források is, amelyek a beszélt nyelvre az egyéni interakció szintjén utalnak. Itt elsősorban a boszorkányperekre és az úriszéki periratokra kell gondolnunk. Segítségükkel a per résztvevői (vádlottak, tanúk) megnyilatkozásainak a nyelve és nevük eredete közötti összefüggés kontrollvizsgálata történhet meg. (Ilyen jellegü elemzésre 1. SzENTGYÖRGYI 2012, HAUBER megj e.).

5. Összegzés. Tanulmányomban arra a kérdésre kerestem a választ, hogy a személynevek lehetne-e az etnikai rekonstrukció forrásai a családnevek kialakulása és a hivatalos családnévhasználat törvényi szabályozása közötti időszakra vonatkozóan.

Az etnikai rekonstrukciós vizsgálatok elsődlegesen a történettudomány és a társadalomföldrajz határterületén elhelyezkedő történeti földrajz érdeklődési körébe tartoznak. Bemutattam azokat a vizsgálati módokat, amelyekben a személynevek jelentették az elsődleges forrást a történeti etnikai vizsgálatokban. Habár a kutatók sok szempontból bizonytalannak tartják a személynevek etnikai forrásértékét, jobb híján mégis felhasználják a személynevek nyelvi sajátosságait a korai csoportidentitások feltárásához. Elemzésükhöz különböző módszereket dolgoztak ki, amelyek között azonban több vitatható megoldást is láthattunk.

Véleményem szerint a személynévi adatok megbízhatósága kapcsán megfogalmazott negatív vélemények felülvizsgálatra szorulnak, mert a kétségtelenül létező névtorzulások és az írnok általi névfordítások esetei csak elenyésző hányadát képviselik egy adott névanyagnak; az eljárás mögött általános gyakorlat semmiképpen sem feltételezhetö. Ennek az ugyanazon írnok feljegyzéseiben szereplő nem magyar nyelvi adatok tömege mond ellent legegyértelmübben. Meggyőződésem, hogy nincs okunk ezt a rendkívül fontos forráscsoportot kirekeszteni sem a nyelvészeti, sem pedig a történettudományi vizsgálatokból.

${ }^{24}$ Hiller Mátyásné, Kadar Mihaly, Bürkös Györgj, Stephanus Sonkolly, Balint János, Johannes Késcsináló. 
A tanulmányban a személynévi alapú etnikai rekonstrukció többszintes vizsgálati módjára tettem javaslatot, melynek lényege a nyelvészeti-névtani és a történettudományi elemzési szempontok és célok egyértelmü elkülönítése. Az eljárás tehát egyértelmüen elválasztja a családnéveredet meghatározását a névviselő egyén etnikai hovatartozásától. Az első szinten kizárólag az etimológiai és névtani kutatás szabályai szerint történik meg a családnéveredet meghatározása, azaz a név nyelvi hátterének feltárása. A másodikon az etnikai összetételre történő utalás valósul meg, melyhez két, egymásra épülő szempontot különítettem el. Egyrészt bizonyos esetekben az egyénnevek nyelvi tanulságait (élőnyelvi adatait) hívhatjuk segítségül, majd azokat az egyéb információkat (pl. társadalmi állás, többségi lakosság nyelvi hovatartozása, más típusú források tanulságai) vonjuk be a vizsgálatba, amelyek közvetlenül vagy közvetve az etnikai háttérre utalnak. Ez ugyan több és hosszabb elemzés elvégzését kívánja meg, viszont ezáltal a szempontkeveredés elkerülhető, így a kapott eredmények is megbízhatóbbá válnak.

\section{Hivatkozott irodalom}

ACSÁdy IGNÁC 1896. Magyarország a Pragmatica Sanctio korában. 1720-1721. Magyar Statisztikai Közlemények Új Folyam 12. Athenaum R. Társulat, Budapest.

BAGDi RÓBERT - DEMETER GÁBOR 2004. Nyelvhatár-változás, asszimilációs helyzetek és a statisztika megbízhatósága Zemplén megye példáján. Tisicum. A Jász-Nagykun-Szolnok megyei múzeumok évkönyve 14: 359-383.

BÁLINT CSANÁD 2006. Az ethnosz a kora középkorban. A kutatás lehetőségei és korlátai. Századok 140: 277-347.

BÉLAY ViLmos 1943. Máramaros megye társadalma és nemzetiségei. A megye betelepülésétöl a XVIII. század elejéig. Település- és Népiségtörténeti Értekezések 7. Sylvester Nyomda R-T., Budapest.

BENKŐ LORÁND 2002. Az ómagyar nyelv tanúságtétele. Perújitás Dél-Erdély korai Árpád-kori történetéröl. Társadalom- és Művelődéstörténeti Tanulmányok 29. MTA Történettudományi Intézet, Budapest.

BHOPAL, RAJ 2004. Glossary of terms relating to ethnicity and race: for reflection and debate. Journal of Epidemiology and Community Health 58: 441-445. http://doi.org/10.1136/jech.2003.013466

BULMER, MARTIN 1996. The ethnic group question in the 1991 Census of population. In: Coleman, David - Salt, John eds., Ethnicity in the 1991 Census. Vol. I. Demographic characterisitics of the ethnic minority populations. Office for National Statistics, HMSO, London. 33-62.

DÁVID ZoLTÁN 1993. A magyar-szlovák nyelvhatár 1664-ben az Érsekújvári ejalet területén. Történeti Demográfiai Füzetek 12: 9-31.

DÁvid ZoLTÁN 1995. Sáros vármegye magyar településeinek pusztulása. Történeti Demográfiai Füzetek 14: 144-180.

DEMETER GÁBOR 2009. A névelemzés: divat vagy történeti rekonstrukciós módszer? Kísérlet a XVIII. századi összeírások migrációs és asszimilációs célú felhasználására. In: DEMETER GÁBOR - BAGDi RÓBERT szerk., Migráció és asszimiláció Északkelet-Magyarországon és a Partiumban 1715-1992. Kossuth Egyetemi Kiadó, Debrecen. 5-11.

DEMETER GÁBOR - BAGDi RÓBERT 2009a. A migráció és asszimiláció a Partiumban 1715-1910. In: DEMETER GÁBOR - BAGDi RóBERT szerk., Migráció és asszimiláció Északkelet-Magyarországon és a Partiumban 1715-1992. Kossuth Egyetemi Kiadó, Debrecen. 24-32. 
DEMETER GÁBOR - BAGDi RÓBERT 2009b. A migráció és a telepítéspolitika hatása Szatmár megye etnikai és demográfiai szerkezetére 1715-1992. In: DEMETER GÁBOR - BAGDI RÓBERT szerk., Migráció és asszimiláció Északkelet-Magyarországon és a Partiumban 1715-1992. Kossuth Egyetemi Kiadó, Debrecen. 12-23.

ERIKSEn, ThOMAS Hylland $2002^{2}$. Ethnicity and nationalism. Anthropological Perspectives. Pluto Press, London.

ERÖS VILMOS 2013. Utak a „Népiségtörténet”-hez. Mályusz Elemér és Szabó István. Századok 147: $33-62$.

FARKAS TAMÁS 2009a. Családnév-változtatás Magyarországon. A névváltoztatások tényezői és története a 20. század második felében. Nyelvtudományi Értekezések 159. Akadémiai Kiadó, Budapest.

FARKAS TAMÁS 2009b. Családnévrendszer, névhasználat, névváltozás nyelvi-kulturális kontaktushelyzetben. Névtani Értesitö 31: 27-46.

FARKAS TAMÁS 2013. Surnames of ethnonymic origin in the Hungarian language. In: FELECAN, OLIVIU ed., Proceedings of the Second International Conference on Onomastics "Name and Naming”. Onomastics in Contemporary Public Space. Editura Mega, Cluj-Napoca. 504-517.

FARKAS TAMÁS 2015. Családnév és etnikum: utak és lehetőségek a magyar és a nemzetközi alkalmazott névtani kutatásokban. In: VÖRÖS FERENC szerk., A nyelvföldrajztól a névföldrajzig VI. Határtalan névföldrajz. UMIZ - Imre Samu Nyelvi Intézet, Unterwart/Alsóör-Budapest. 187-211.

FEHÉRTÓI KATALIN 1997. Árpád-kori közszói eredetű személyneveinkről. Magyar Nyelvőr 121: $71-75$.

N. FODOR JÁNOS 2010. Személynevek rendszere a kései ómagyar korban. Magyar Névtani Értekezések 2. ELTE BTK, Budapest.

N. FODOR JÁNOS 2014. A történeti személynévföldrajz mint a nyelvföldrajz egyik kutatási területe 1. A nyelvföldrajzi módszer a névtani kutatásokban. Névtani Értesitő 36: 23-41.

N. FODOR JÁNOS 2015a. Interferenciális jelenségek és névromlások esetei a 18. század eleji személynév-történeti forrásanyagban. In: KALCSÓ GYULA szerk., Tanulmányok a magyar nyelvröl. Acta Academiae Paedagogicae Agriensis. Nova Series Tom. XLII. Sectio Linguistica Hungarica. Eszterházy Károly Főiskola, Eger. 159-167.

N. FODOR JÁNOS 2015b. Language contact effects in historical Hungarian and Romanian personal names. In: Oliviu Felecan ed., Name and Naming. Proceedings of the Third International Conference on Onomastics "Name and Naming". Conventional / Unconventional in Onomastics. Editura Mega - Editura Argonaut, Cluj-Napoca. 163-173.

N. FODOR JÁNOS 2016. A történeti személynévföldrajzi kutatások újabb perspektívái. In: BENÖ Attila - T. Szabó Csilla szerk., Az ember és a nyelv - térben és időben. Erdélyi MúzeumEgyesület, Kolozsvár. 89-105.

FTSznSz. $=$ N. FODOR JÁNOS 2010. A Felsö-Tisza-vidék késö középkori személyneveinek szótára (1401-1526). Magyar Névtani Értekezések 3. ELTE BTK, Budapest.

HAUBER KitTI megj. e. Személynév - nyelvhasználat - etnikum korrelációja a 17-18. századi boszorkányperekben. In: BÁTORI GYOPÁR - KOROMPAY ESZTER - SZABÓ GERGELY szerk., Anyanyelvünk évszázadai 5. Studia Iuvenum Chronolinguistica 6. Napkút Kiadó - ELTE BTK Magyar Nyelvtörténeti, Szociolingvisztikai, Dialektológiai Tanszék, Budapest. Megjelenés előtt.

HOFFMANN ISTVÁN 2007. Nyelvi rekonstrukció - etnikai rekonstrukció. In: HofFMANN IsTVÁN JuHÁsz Dezső szerk., Nyelvi identitás és a nyelv dimenziói. Nemzetközi Magyarságtudományi Társaság, Debrecen-Budapest. 11-20.

HofFMANN ISTVÁN 2010. Név és identitás. Magyar Nyelvjárások 48: 49-58. 
HofFMANN IsTVÁN - TóTH VALÉRIA 2015. Szempontok a 11. századi nyelvi és etnikai rekonstrukció kérdéséhez. Helynévtörténeti Tanulmányok 11: 7-16.

HOFFMANN ISTVÁN - TÓTH VALÉRIA 2016. A nyelvi és etnikai rekonstrukció kérdései a 11. századi Kárpát-medencében. Századok 150: 257-318.

HofFMANN ISTVÁN - RÁCZ ANITA - TÓTH VALÉRIa 2018. Régi magyar helynévadás. Gondolat Kiadó, Budapest.

IczKovits Eмma 1939. Az erdélyi Fehér megye a középkorban. Település- és Népiségtörténeti Értekezések 2. Sylvester Irodalmi és Nyomdai Intézet, Budapest.

ILA BÁLINT 1944-1976. Gömör megye. MTA/Akadémiai Kiadó, Budapest.

JAKÓ ZsIGMOND 1940. Bihar megye a török pusztítás elött. Település- és Népiségtörténeti Értekezések 5. Sylvester Nyomda Rt., Budapest.

KÁZMÉr Miklós 1981. Párhuzamos személynévadás. In: HAJdú MiHÁLY - RÁCz ENDRE szerk., Név és társadalom. A III. Magyar Névtudományi Konferencia elöadásai. (Veszprém, 1980. szeptember 22-24.). A Magyar Nyelvtudományi Társaság Kiadványai 160. Magyar Nyelvtudományi Társaság, Budapest. 43-46.

KNIEZSA IstVÁN 1934/1965/2003. Felvidéki családnevek. In: KNIEZSA IstvÁN, Helynév-és családnévvizsgálatok. Lucidus Kiadó, Budapest. 268-349.

KNIEZSA IsTVÁN 1938. Magyarország népei a XI.-ik században. In: SERÉDi JuszTINIÁN szerk., Emlékkönyv Szent István király halálának kilencszázadik évfordulóján 1-2. MTA, Budapest. 2: $365-472$.

KNIEZSA IsTVÁN 1941. Adalékok a magyar-szlovák nyelvhatár történetéhez. Athenaeum, Budapest.

KRISTÓ GYULA 2000. Magyarország népei Szent István korában. Századok 134: 3-44.

LEE, JiNHYUK et al. 2017. Name Nationality Classification with Recurrent Neural Networks. In: CARLES SIERRA ed., Proceedings of the Twenty-Sixth International Joint Conference on Artificial Intelligence. Melbourne, Australia, 19-26 August 2017. 2081-2087. https://doi.org/10.24963/ ijcai.2017/289

Mateos, Pablo 2007. A Review of Name-based Ethnicity Classification Methods and their Potential in Population Studies. Population, Space and Place 13: 243-263. https://doi.org/10.1002/psp.457

Mateos, Pablo 2014. Names, Ethnicity and Population. Tracing Identity in Space. Advances in Spatial Science. Springer-Verlag, Berlin-Heidelberg. https://doi.org/10.1007/978-3-642-45413-4

Melich János 1925-1929. A honfoglaláskori Magyarország. Akadémiai Kiadó, Budapest.

PEACH, CERI ed. 1996. Ethnicity in the 1991 Census. Vol. II. The ethnic minority popupations of Great Britain. Office for National Statistics, HMSO, London.

Póczos Rita 2010. Nyelvi érintkezések és a helynévrendszerek kölcsönhatása. A Magyar Névarchívum Kiadványai 18. Debreceni Egyetemi Kiadó, Debrecen.

RÁCZ ANITA 2011. Adatok a népnévvel alakult régi településneveink történetéhez. A Magyar Névarchívum Kiadványai 19. Debreceni Egyetemi Kiadó, Debrecen.

RáCz ANITA 2013. A nép(név) fogalmának változása, értelmezése. Helynévtörténeti Tanulmányok 9: 7-17.

RÁCZ ANITA 2016. Etnonimák a régi magyar településnevekben. A Magyar Névarchívum Kiadványai 37. Debreceni Egyetemi Kiadó, Debrecen.

RÓNA-TAS ANDRÁS 1996. A honfoglaló magyar nép. Bevezetés a korai magyar történelem ismeretébe. Balassi Kiadó, Budapest.

RÓNA-TAS ANDRÁS 1997. A néppé válás az újabb kutatások tükrében. In: PALÁDI-KovÁCS ATTILAKovÁcs LÁszLó szerk., Honfoglalás és néprajz. Balassi Kiadó, Budapest. 23-32. 
Szempontok és módszerek a személynév és etnikum összefüggésének...

SLíz MARIANN 2014. Személynevek fordítása kései ómagyar kori okleveleinkben. Magyar Nyelvjárások 52: 73-88.

SLíz MARIANN 2017. Személynévtörténeti vizsgálatok a középkori Magyarországról. Magyar Nyelvtudományi Társaság. Budapest. https://doi.org/10.26546/5061134

Slíz Mariann - P. Tóth TeOdóRA - Farkas TAMÁs 2018. Mitől magyar egy családnév? A családnevek etnikai-nyelvi alapú, többségi és kisebbségi szempontú laikus kategorizációjának vizsgálata kulturális nyelvészeti keretben. In: VÖRÖS FERENC - LEHOCKI-SAMARDŽIĆ ANNA szerk., A nyelvföldrajztól a névföldrajzig $I X$. Név és társadalom a magyar nyelvterület peremén. Savaria University Press - Glotta Nyelvi Intézet, Szombathely-Osijek. 37-58.

SzABÓ IstVÁN 1937. Ugocsa megye. Magyarság és nemzetiség. Tanulmányok a magyar népiségtörténet köréből I. sorozat 1. kötet. MTA, Budapest.

SZENTGYÖRGYI RUDOLF 2012. Név, anyanyelv, identitás összefüggései a középmagyar kor boszorkánypereinek tükrében. Helynévtörténeti Tanulmányok 7: 133-142.

TMCsA. = Történeti magyar családnévatlasz. Elektronikusan tárolt adatbázis. 2011-. Kutatásvezetö: N. FODOR JÁNOS.

TóTH VALÉRIA 2013. Szempontok a középkori források személynévi adatainak értékeléséhez. Nyelvtudományi Közlemények 109: 227-254.

TóTH VALÉRIA 2016. Személynévadás és személynévhasználat az ómagyar korban. A Magyar Névarchívum Kiadványai 38. Debreceni Egyetemi Kiadó, Debrecen.

VÖRÖS FERENC 2016. Családnév-regionalizmusok a 18. század eleji Magyar Királyság nyugati térségéből. In: VÖRÖS FERENC szerk., A nyelvföldrajztól a névföldrajzig VII. Névregionalizmusok. Savaria University Press, Szombathely. 11-38.

VÖRÖS FERENC 2018. Peremvidéki családnév-etimológiák nyelvföldrajzáról. In: VÖRÖS FERENC LEHOCKI-SAMARDŽIĆ ANNA szerk., A nyelvföldrajztól a névföldrajzig IX. Név és társadalom a magyar nyelvterület peremén. Savaria University Press - Glotta Nyelvi Intézet, SzombathelyOsijek. 17-33.

N. FODOR JÁNOS

ORCID: https://orcid.org/0000-0002-0401-3701

ELTE Eötvös Loránd Tudományegyetem Bölcsészettudományi Kar

\section{JÁNOS N. FODOR, Aspects and methods for examining the connection between personal names and ethnicity}

It is a difficult task to determine the value of proper names in ethnic reconstruction. This can be considered a dubious area of onomastic/linguistic and historical research. Even the explanation of the basic concepts seems to be problematic; still, defining ethnicity and identifying the nature of the connection between ethnicity and language cannot be avoided. It is also important to define the value of the different types of personal names as sources: what can and cannot the research into the etymology of surnames be used for, what are the factors that have an impact on linguistic reconstruction, how can individual names help ethnic reconstruction, etc. After summarizing the background research of name analysis in Hungary, the author presents a multi-level method of ethnic reconstruction based on personal names. The procedure tries to separate the determination of the name's etymology from that of the ethnic affiliation, placing the examination objectives at separate 
levels. On the first level, the etymology of the surnames is determined and the linguistic background of the name is explored by considering linguistic aspects only, paying attention to the rules of etymological and onomastic research. The author separates two levels of the examination of ethnic reconstruction that are built upon each other. On the one hand, the linguistic features of the individual names are observed, and then other information on name sociology (e.g. social status, majority population), referring directly or indirectly to ethnic background, is taken into consideration. 